УДК $621.7,62-4$

[0000-0002-2166-7766] В. І. Осипенко, д.т.н., професор, ${ }^{[0000-0001-8637-8749]}$ О. В. Тімченко, ${ }^{[0000-0002-5055-1068]}$ А. В. Кондаков

Черкаський державний технологічний університет б-р Шевченка, 460, м. Черкаси, 18006, Україна

\title{
МОДЕЛЮВАННЯ ТЕПЛОВИХ ПРОЦЕСІВ ФОРМУВАННЯ ОДИНИЧНОЇ ЛУНКИ РОЗРЯДАМИ СУЧАСНИХ ГЕНЕРАТОРІВ ЕЛЕКТРОЕРОЗІЙНИХ ВИРІЗНИХ ВЕРСТАТІВ
}

Розглянуто особливості формування геометрї̈ одиничної лунки та глибини зони термічного впливу при електроерозійній обробиі якісної конструкиійної сталі 45 дротяним електродом на верстатах, оснащених сучасними генераторами технологічного струму. Математичним моделюванням на основі чисельних розв'язків осесиметричної квазітрифазної нелінійної задачі теплопровідності з рухомими гранииями фаз отримано криві, ще описують межі фаз випаровування, плавлення матеріалу $і$ температури аустенітних перетворень залежно від енергетичних параметрів розряду та теплофізичних характеристик матеріалу деталі. Виконано оцінювання об 'ємів матеріалу, щзо видалясться з лунки у вигляді пари та рідини. Наведено дані про величини енергій, що витрачаються на фазові перетворення матеріалу анода: плавлення та випаровування, їх частку в загальній енергії розряду, щңо виділясться на сталевому аноді на різних режимах обробки, а також наслідки зміни параметрів імпульсів на кожному з режимів. Виявлено, що збільшення тривалості імпульсу при збільшенні загальної енергії, що реалізується в міжелектродному проміжку, призводить до зменшення ефективності використання иієї енергії при руйнуванні матеріалу заготовки. Адекватність моделі оиінювалась зіставленням з експериментальними даними, які були неодноразово підтверджені на обладнанні різних підприємств. Отримані результати відкривають перспективний шлях до мінімізаиї енергетичних затрат на обробку того чи іншого матеріалу та керування характеристиками оброблених поверхонь як з точки зору формування мікрогеометрії, так і глибини зміни структури в зоні термічного впливу, що, в свою чергу, дасть змогу розширити межі застосування електроерозійної технології за рахунок підвищення економічної вигоди від використання описаної методики. Окрім того, створюється підгрунтя для ефективного проектування технологічних режимів подальшої електрохімічної розмірної обробки незмінним дротяним електродом, оскільки глибина зони термічного впливу є важливим фактором при визначенні припуску, який має бути видалений при електрохімічній модифікаиії поверхні.

Ключові слова: електроерозійна обробка, енергія імпульсу, зона термічного впливу.

Вступ. Електроерозійна технологія $\epsilon$ одним із найсучасніших та найпоширеніших методів обробки металів. У групі електроерозійного технологічного обладнання переважний розвиток мають вирізні верстати завдяки високій ефективності електроерозійного дротяного вирізання (ЕЕДВ) при виготовленні точних складноконтурних деталей інструментального виробництва.

В світі на підприємствах машинобудівної, приладобудівної, авіаційної промисловості працюють десятки тисяч електроерозійних вирізних верстатів різних виробників 3 широким спектром технічних і технологічних параметрів. Поверхня деталей, отримана електроерозійним способом, має характерні ознаки.
Вона формується послідовним накладанням лунок, утворених окремими розрядами. Форма та геометричні розміри лунок визначають продуктивність процесу i мікрогеометрію утворених поверхонь. По суті, вони є складними багатофакторними функціями технологічних параметрів обробки, серед яких домінують параметри джерела тепла і теплофізичні характеристики поверхневих шарів деталі. В умовах жорсткої конкуренції триває безупинна боротьба за краще співвідношення ціна/якість у різних сегментах ринку. При цьому досягнуті результати, як правило, грунтуються на чисто емпіричних підходах, певною мірою ігноруючи сучасні можливості математичного моделювання в розкритті та аналізі

(C) В. І. Осипенко, О. В. Тімченко, А. В. Кондаков, 2019 DOI: 10.24025/2306-4412.3.2019.182555 
сутності процесів взаємодії надкоротких розрядів, що формуються сучасними генераторами, 3 матеріалом заготовки. Спробі обгрунтування можливостей використання математичного моделювання для ефективного прогнозування заданих результатів електроерозійного дротяного вирізання і присвячено цю роботу.

Мета. Обгрунтувати можливості та оцінити адекватність використання математичного моделювання для прогнозування мікрогеометрії поверхонь, характеристик зони термічного впливу та енергоефективності режимів роботи сучасних генераторів електроерозійних вирізних верстатів.

Задачі. 1. Шляхом математичного моделювання на основі чисельних розв'язків осесиметричної квазітрифазної нелінійної задачі теплопровідності з рухомими границями фаз встановити форми границь фазових переходів при використанні енергетичних параметрів одиничних імпульсів, характерних для фінішного, напівчистового та чорнового режимів обробки сталей сучасного електроерозійного комплексу AccuteX GE-43SA.

2. Спираючись на отримані результати, оцінити енергоефективність обраних режимів генератора електроерозійного комплексу AccuteX GE-43SA.

3. Оцінити адекватність математичного моделювання шляхом зіставлення розрахункових та експериментальних даних.

Аналіз останніх досліджень. Проблема моделювання теплових процесів при формуванні одиничної ерозійної лунки є вкрай складною та актуальною. Оскільки поверхня деталі формується завдяки накладанню лунок від одиничних імпульсів, то саме форма і розміри лунок визначатимуть параметрі продуктивності та шорсткості.

Розмір одиничної лунки залежить від низки технологічних параметрів. У роботах $[1,2]$ показано, що основний вплив на баланс енергії одиничного іскрового розряду мають тривалість імпульсу струму, фізико-хімічні властивості поверхневих шарів дротяного електрода, величина міжелектродного проміжку. Вдало підібрані параметри можуть забезпечити суттєву теплову асиметрію розряду. При цьому більше 80 \% енергії, що надійшла в міжелектродний проміжок, може бути витрачено на руйнування матеріалу деталі.

Характер процесу формування лунки залежить від густини потужності. За однакової енергії імпульсу більший канал розряду призводить до утворення неглибокої лунки 3 пласким дном, яка характерна для чистових та напівчистових режимів обробки, а менший діаметр каналу розряду - до більш глибоких лунок, характерних для чорнових режимів обробки [3]. Використання різних типів поверхнево-активних речовин (ПАР) може збільшити діаметр каналу розряду майже в два рази, відповідно в чотири рази зменшується густина потужності в каналі розряду, змінюється динаміка процесів плавлення та випаровування.

Теплофізичні характеристики матеріалу аноду (деталі) визначають швидкість поширення тепла вглиб матеріалу, кількість енергії, що має бути витрачена на нагрівання матеріалу та фазові перетворення.

В роботі [4] було визначено чотири форми одиничних електроерозійних лунок: круговий циліндр, напівеліпсоїд обертання, параболоїд обертання, конус. Форма лунки залежить від розподілу потужності джерела тепла, теплофізичних параметрів матеріалу електрода, тривалості імпульсу струму тощо. В роботі [1] показано, що, крім енергії імпульсу та густини потужності, важливим показником є також крутизна заднього фронту імпульсу струму. Вона визначає швидкість схлопування каналу розряду, а відповідно, і величину сил, що призводять до викиду розплаву із дна лунки.

В плані використання методів математичного моделювання [7-10] дослідники значно просунулися в наближенні теоретичних моделей до реальних умов перебігу процесу одиничного розряду при використанні довготривалих імпульсів, характерних для технологій електроерозійної копіювально-прошивної обробки. Хоча процеси, що відбуваються під час пробою і після пробою в каналі розряду надкоротких імпульсів, які формуються сучасними генераторами, схожі на процеси імпульсів великої тривалості, для надкоротких імпульсів характерна наявність суттєвої частки випаруваного матеріалу в зоні контакту плазми каналу з матеріалом заготовки [1]. В жодній із розглянутих моделей не проводилось моделювання зміни фаз з урахуванням границі випаровування. Більшість розглянутих моделей також не враховують зміну енергетичних параметрів каналу розряду як функції часу.

Виклад основного матеріалу. Розвиток елементної бази дає можливість навіть у відносно дешевих верстатах реалізувати режими 
3 максимальним струмом до 1000 А та тривалістю імпульсу від 0,05 мкс. У таблиці 1 наведено параметри генератора технологічного струму електроерозійного комплексу AccuteX GE-43SA, що є типовим представником обладнання середнього цінового діапазону.

Таблиця 1 - Діапазон електричних параметрів генератора технологічного струму електроерозійного комплексу AccuteX GE-43SA

\begin{tabular}{|c|c|c|c|c|}
\hline № & \multirow{2}{*}{ Параметр } & \multirow{2}{*}{ Розмірність } & \multicolumn{2}{|c|}{ Значення } \\
\hline $3 / \Pi$ & & & мінімальне & максимальне \\
\hline 1 & Тривалість імпульсу струму & мкс & 0,05 & 1,2 \\
\hline 2 & Амплітудне значення імпульсу струму & A & 33 & 800 \\
\hline 3 & Тривалість паузи між імпульсами & мкс & 4 & 50 \\
\hline 4 & Енергія імпульсу & мДж & 0,025 & 36 \\
\hline 5 & Крутизна фронтів струму & $\mathrm{A} / \mathrm{c}$ & $1 \cdot 10^{8}$ & $2 \cdot 10^{9}$ \\
\hline
\end{tabular}

Осцилограму струму та напруги одиничного іскрового розряду при використанні режиму № 3 (таблиця 2) генератора технологічного струму електроерозійного комплексу
AccuteX GE-43SA зображено на рисунку 1. Імпульс робочого струму відповідає IV ділянці осцилограми і має трикутну рівнобічну форму.

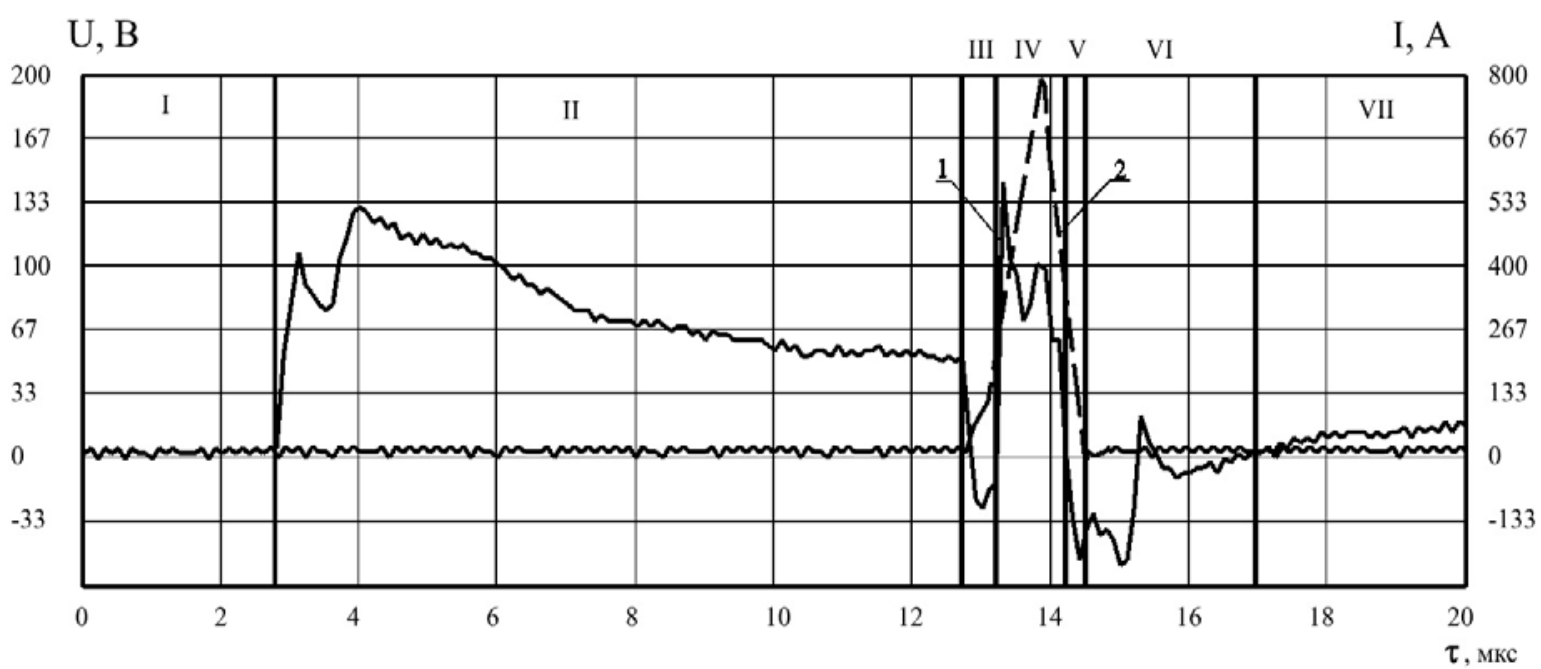

1 - напруга на проміжку; 2 - струм розряду; I - пауза перед імпульсом напруги;

II - напруга пробою проміжку; III - визначення наявності пробою і комутація потужного джерела струму; IV - імпульс робочого струму; V - схлопування каналу розряду;

VI - електричні збурення від припинення розряду; VII - пауза між імпульсами

Рисунок 1 - Осцилограма струму та напруги одиничного іскрового розряду

Для забезпечення необхідних параметрів мікрогеометрії та точності сучасних деталей електроерозійне вирізання, як правило, проводиться в кілька проходів з різними енергетичними режимами - від чорнових (з високою продуктивністю повного зйому матеріалу і погіршеними параметрами точності й шорсткості поверхні) до фінішних режимів додаткового різання (з низькою продуктивністю руйнування, але з високими параметрами точності та мікрогеометрії). В таблиці 2 наведені дані отримані розрахунково-експериментальним шляхом, 3 використанням рівнянь DOI: 10.24025/2306-4412.3.2019.182555

балансу енергії одиничного іскрового розряду [5], найбільш широко вживані для обробки сталей енергетичні параметри електроерозійного комплексу AccuteX GE-43SA.

Імпульсні розряди струму, що проходять між електродами, викликають їх нагрівання. Для визначення розподілу температур в матеріалі деталі застосуємо математичне моделювання. В роботі [1] представлена математична модель, яка $€$ розв'язком осесиметричної квазітрифазної нелінійної задачі теплопровідності з рухомими границями фаз (задача Стефана). 
Таблиця 2 - Енергетичні параметри характерні для фінішного, напівчистового та чорнового режимів обробки сталей електроерозійного комплексу AccuteX GE-43SA

\begin{tabular}{|c|c|c|c|c|c|}
\hline $\begin{array}{c}\text { № } \\
\text { 3/п }\end{array}$ & $\begin{array}{c}\text { Тривалість } \\
\text { імпульсу, } \\
\text { мкс }\end{array}$ & $\begin{array}{c}\text { Амплітудне } \\
\text { значення струму, } \\
\text { А }\end{array}$ & $\begin{array}{c}\text { Енергія, що } \\
\text { реалізується на } \\
\text { аноді, Еа, мДж }\end{array}$ & $\begin{array}{c}\text { Діаметр } \\
\text { лунки, мкм }\end{array}$ & $\begin{array}{c}\text { Густина потужнос- } \\
\text { ті, } q, 10^{12} \mathrm{BT} / \mathrm{m}^{2}\end{array}$ \\
\hline 1 & 0,05 & 33 & 0,02 & 20 & 1,27 \\
\hline 2 & 0,7 & 467 & 7,249 & 66 & 3,07 \\
\hline 3 & 1,2 & 800 & 28,831 & 101 & 3,03 \\
\hline
\end{tabular}

В циліндричній системі координат вихідна система рівнянь має такий вигляд:

$$
\begin{gathered}
\rho C_{1}(T) \frac{\partial T_{1}}{\partial t}=\frac{1}{r} \frac{\partial}{\partial r}\left[\lambda_{1}(T) r \frac{\partial T_{1}}{\partial r}\right]+\frac{\partial}{\partial z}\left[\lambda_{1}(T) \frac{\partial T_{1}}{\partial z}\right], \quad \xi(t)<r, z ; \\
\rho C_{2}(T) \frac{\partial T_{2}}{\partial t}=\frac{1}{r} \frac{\partial}{\partial r}\left[\lambda_{2}(T) r \frac{\partial T_{2}}{\partial r}\right]+\frac{\partial}{\partial z}\left[\lambda_{2}(T) \frac{\partial T_{2}}{\partial z}\right], \quad \eta(t)<r, z<\xi(t),
\end{gathered}
$$

де $T_{1}(r, z, t)$ - температурне поле твердої фази електрода;

$T_{2}(r, z, t)$ - температурне поле рідкої фази електрода;

$\rho$ - густина матеріалу електрода;

$C_{1}(T), \quad \lambda_{1}(T)$ - питома теплоємність та коефіцієнт теплопровідності твердої фази матеріалу електрода;

$C_{2}(T), \lambda_{2}(T)$ - питома теплоємність та коефіцієнт теплопровідності рідкої фази матеріалу електрода;

$\xi(t)$ - положення рухомої границі між рідкою та твердою фазами матеріалу електрода;

$\eta(t)$ - рухома границя випаровування матеріалу електрода.

Тепловий потік, що надходить від каналу розряду до поверхні анода, може бути записаний у вигляді

$$
q(r, t)=4,5 q_{\tau}(t) e^{-4,5 \frac{r^{2}}{r_{0}^{2}}},
$$

де $q_{\tau}(t)$ - залежність густини теплового потоку від часу впродовж тривалості розряду;

$r_{0}$ - радіус одиничної ерозійної лунки;

$r$ - поточна відстань від центру симетрії джерела тепла.

Залежність $q_{\tau}(t)$ розраховується для кожного режиму окремо шляхом апроксимації експериментально отриманих вольтамперних характеристик розряду та даних про відповідні діаметри ерозійних лунок. Так, для імпульсу тривалістю 0,6 мкс вона може бути описана таким чином:

$$
\begin{aligned}
& q_{\tau}(t)=4,3 q_{0}\left(-\sin \left(45 \cdot 10^{5} t+2,76\right)\right) \cdot e^{-24 \cdot 10^{5} t-0,56}, \\
& \mid \begin{array}{l}
0<t<8,5 \cdot 10^{-8} c \rightarrow q_{\tau}(t)=0, \\
8,5 \cdot 10^{-8} c<t<6,85 \cdot 10^{-7} c \rightarrow q_{\tau}(t), \\
6,85 \cdot 10^{-7} c<t<\infty \rightarrow q_{\tau}(t)=0 .
\end{array}
\end{aligned}
$$

де $q_{0}$ - амплітудне значення густини потужності.

Початкові умови:

$$
\left.T_{1}\right|_{t=0}=\left.T_{2}\right|_{t=0}=T_{0} .
$$

Граничні умови:

$$
\begin{aligned}
& \left.\frac{\partial T_{1}}{\partial r}\right|_{r=0}=\left.\frac{\partial T_{2}}{\partial r}\right|_{r=0}=0 ;\left.\quad \frac{\partial T_{1}}{\partial r}\right|_{r=r_{N 1}}=0 ; \\
& \left.\frac{\partial T_{2}}{\partial z}\right|_{z=\eta(t)}=q(r, t) ;\left.\quad \frac{\partial T_{1}}{\partial z}\right|_{z=z_{N 2}}=0,
\end{aligned}
$$

де $q(r, t)$ - функція розподілу інтенсивності теплового потоку від дії плазми каналу одиничного іскрового розряду.

Умови на рухомих границях фаз:

при $r, z=\xi(t)$ :

$$
\begin{gathered}
T_{1}(r, z)=T_{2}(r, z)=T_{n л} \\
\lambda_{1}\left(\frac{\partial T_{1}}{\partial r}+\frac{\partial T_{1}}{\partial z}\right)-\lambda_{2}\left(\frac{\partial T_{2}}{\partial r}+\frac{\partial T_{2}}{\partial z}\right)=\rho L_{n л} \frac{\partial \xi}{\partial t}
\end{gathered}
$$


при $r, z=\eta(t): T_{2}(r, z)=T_{\text {вun }}$;

$$
\lambda_{2}\left(\frac{\partial T_{2}}{\partial r}+\frac{\partial T_{2}}{\partial z}\right)=\rho L_{\text {вun }} \frac{\partial \eta}{\partial t},
$$

де $T_{n л}, T_{\text {виn }}$ - температури плавлення та випаровування матеріалу електрода; $L_{n л}, L_{\text {виn }}-$ питома теплота плавлення та випаровування матеріалу електрода.

При розв'язку задачі враховано, що теплофізичні параметри матеріалу змінюються при зміні фаз і при зміні температури, і є перервними в точках фазових перетворень.

Використання математичного моделювання 3 урахуванням енергетичних параметрів конкретного обладнання, теплофізичних характеристик матеріалу електрода дає можливість побудувати теплові поля, визначити об'єми випаруваного та розплавленого матеріалів, а відтак прогнозувати технологічні показники якості поверхні.

Одним із параметрів, що визначає величину припуску для електрохімічної розмірної обробки (ЕХРО) рухомим дротяним електродом-інструментом (ДЕІ) за технологічної схеми електроерозійного дротяного вирізання, є товщина зони термічного впливу. Для сталей ця зона визначається за наявністю гартувальних структур. Гартувальні перетворення аустеніту в мартенсит можливі лише у випадку, коли сталь має температуру, вищу лінії GPSK на діаграмі стану «залізоцеметит» (для якісних конструкційних та інструментальних сталей $-727^{\circ} \mathrm{C}$ ) [6]. Швидкість охолодження матеріалу після завершення дії імпульсу вища критичної $v_{\kappa p}$, відповідно структура загартованого шару буде містити дрібнозернистий мартенсит та аустеніт, що відповідає експериментальним даним по твердості поверхні [7].

Використовуючи представлену математичну модель, проведено моделювання теплових полів, що виникають від дії одиничного імпульсу згідно з режимами 1-3 (таблиця 2) в якісній конструкційній сталі 45 (ГОСТ 1050-88).

На рисунку 2 зображено форми границі випаровування, плавлення та ізотерми $727^{\circ} \mathrm{C}$ на момент закінчення дії імпульсу струму.

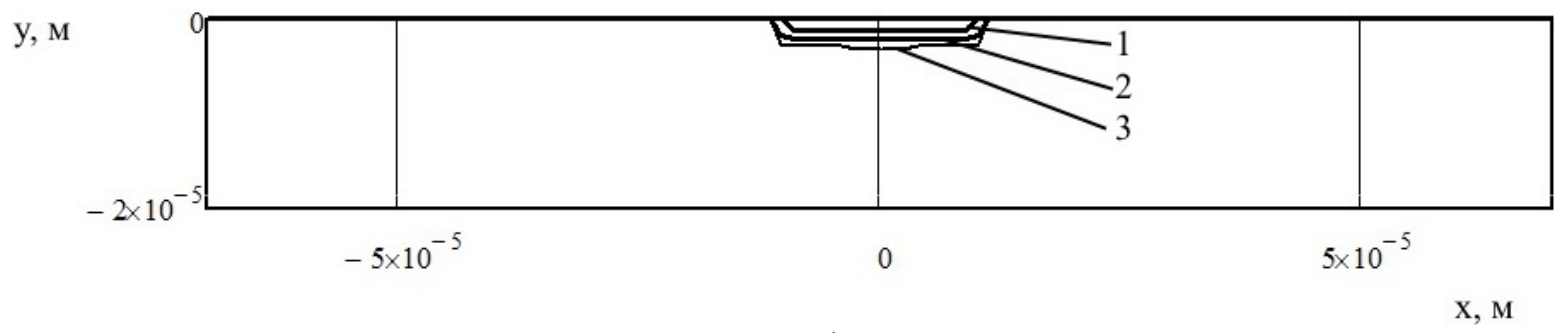

a)

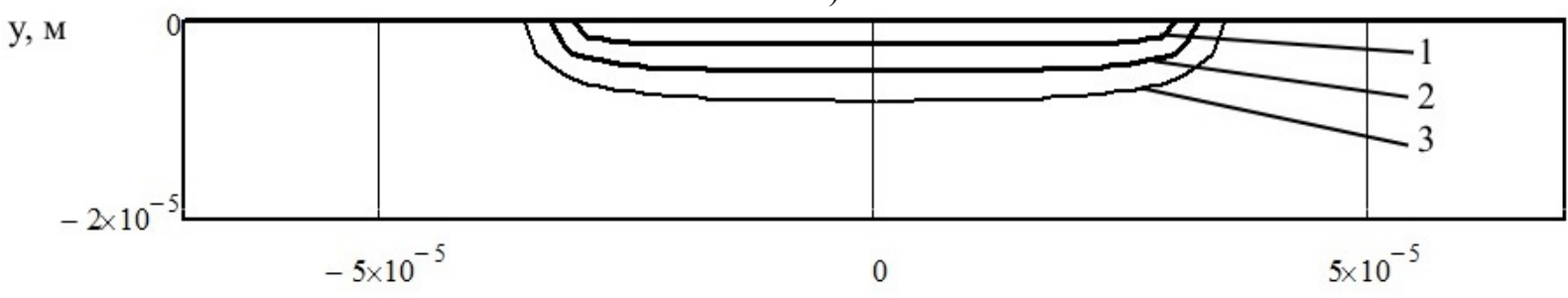

$\mathrm{X}, \mathrm{M}$

б)

$\mathrm{y}, \mathrm{M}$

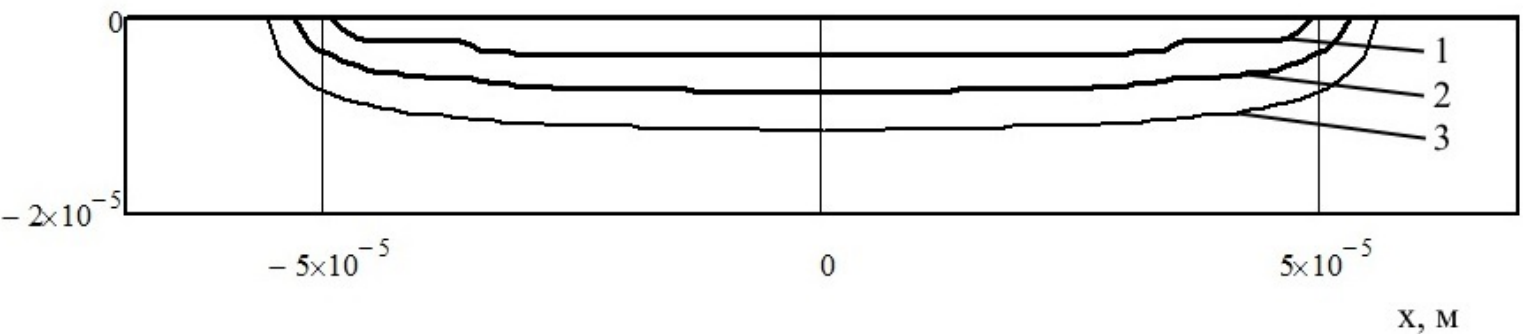

B)

$1-$ границя зони випаровування $\left(\right.$ Твип $\left.=2735^{\circ} \mathrm{C}\right) ; 2-$ границя зони плавлення $\left(\right.$ Тпл $\left.=1527^{\circ} \mathrm{C}\right)$ 3 - ізотерма $727^{\circ} \mathrm{C}$ (на момент закінчення імпульсу струму)

Рисунок 2 - Форми границь фазових переходів для режимів № 1 (а), № 2 (б), № 3 (в) (таблиця 2) 
Враховуючи, що лунка $є$ осесиметричною, можна розрахувати об'єми, маси матеріалу та енергії, що витрачені на фазові пере- творення та нагрівання розплаву до температури випаровування. Отримані дані зведені в таблицю 3.

Таблиця 3 - Розраховані об'єми фазових перетворень матеріалу анода та мінімальна кількість енергії, що витрачена на них

\begin{tabular}{|c|c|c|c|c|c|c|c|c|}
\hline $\begin{array}{l}\text { № } \\
\text { 3/П }\end{array}$ & 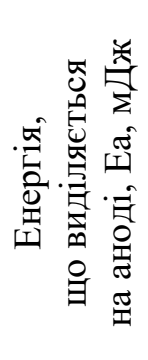 & 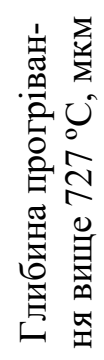 & 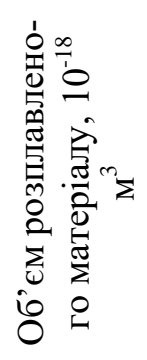 & 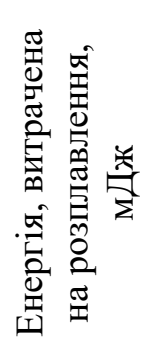 & 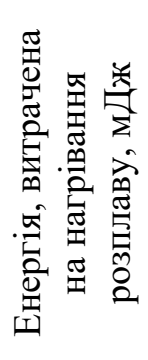 & 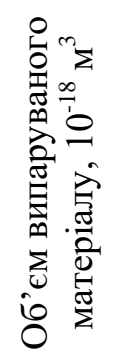 & 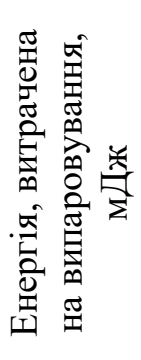 & 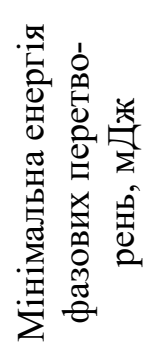 \\
\hline 1 & 0,02 & 3,16 & 881 & 0,0014 & 0,0038 & 414 & 0,022 & 0,026 \\
\hline 2 & 7,249 & 8,36 & 15400 & 0,0253 & 0,0634 & 6940 & 0,360 & 0,448 \\
\hline 3 & 28,831 & 11,67 & 53800 & 0,0890 & 0,215 & 23400 & 1,220 & 1,500 \\
\hline
\end{tabular}

Як видно 3 таблиці, збільшення енергії імпульсу призводить до збільшення енергії, що витрачена на руйнування матеріалу. Однак у відносному значенні ця частка енергії зменшується зі $100 \%$ для чистового режиму до $5 \%$ для чорнового режиму. Тобто модель показує, що реальне збільшення енергії імпульсу призводить до суттєвого зниження енергетичної ефективності процесу різання (рисунок 3). Окрім того, вимога збіжності математичної моделі вимагає певного співвідношення між розмірами сітки за координатою і часом. При менш потужних режимах збільшується похибка визначення об'ємів матеріалу і енергій.

Після закінчення дії імпульсу канал розряду схлопується і частина розплаву викида-

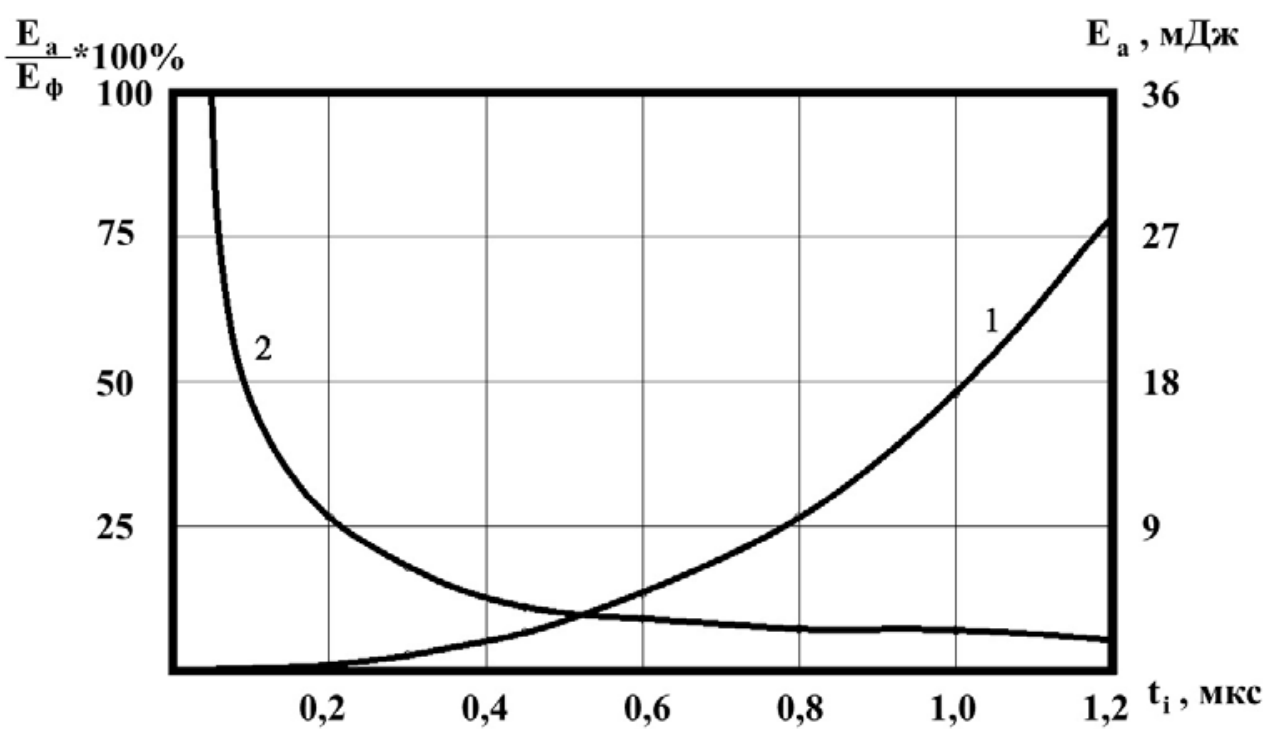

1 - абсолютне значення енергії; 2 - частина енергії, що витрачена на фазові перетворення

Рисунок 3 - Ефективність використання енергії, що виділясться на аноді

(c) В. І. Осипенко, О. В. Тімченко, А. В. Кондаков, 2019

DOI: 10.24025/2306-4412.3.2019.182555 ється в робочу рідину, частина утворює буртик навколо лунки, а частина залишається на дні лунки і кристалізується. Відношення об'єму викинутого матеріалу до розплавленого називають коефіцієнтом викиду (Квик), а його значення залежно від режиму обробки змінюється від $20 \%$ до $80 \%$. Отже, реальна глибина лунки буде знаходитися між межею зони плавлення та межею зони випаровування. Це необхідно враховувати при оцінюванні товщини зони термічного впливу. Товщина термічно зміцненого шару буде становити $\approx 2$ мкм для режиму $1, \approx 5$ мкм для режиму $2 \mathrm{i}$ $\approx 6$ мкм для режиму 3 (таблиця 2). 
Для перевірки адекватності побудованої моделі та прийнятих припущень порівняємо отримані дані 3 експериментом. Продуктивність обробки визначається інтегральними показниками - середньою енергією імпульсу та коефіцієнтом використання імпульсів. Сумарний об’єм видаленого матеріалу можна встановити, виходячи $з$ продуктивності обробки та ширини між-електродного проміжку. Середній розмір одиничної лунки можна порахувати за формулою

$$
V_{\text {cep }}=\frac{V_{H S} \cdot h \cdot\left(2 \cdot \Delta+d_{e n}\right)}{f \cdot t \cdot \eta},
$$

де $V_{H S}$ - швидкість різання;

$h$ - висота заготовки;

$D$ - величина міжелектродного проміжку;

$d_{e л}-$ діаметр дротяного електрода;

$f$ - частота імпульсів;

$t$ - час обробки;

$\eta$ - коефіцієнт використання імпульсів.

Розраховані та експериментальні дані зведені в таблицю 4.

Таблиця 4 - Порівняння розрахованих об’смів фазових перетворень матеріалу анода з експериментальними

\begin{tabular}{|c|c|c|c|c|c|c|c|c|c|c|}
\hline $\begin{array}{l}\text { № } \\
\text { 3/ח }\end{array}$ & $\begin{array}{c}V_{H S} \\
\mathrm{MM} / \mathrm{xB}\end{array}$ & $h, \mathrm{MM}$ & $D$, мм & $d_{e л}, \mathrm{MM}$ & $\begin{array}{c}f, \\
\kappa \Gamma_{ц}\end{array}$ & $t, \mathrm{c}$ & $\eta$ & $\begin{array}{c}\text { Vcep, } \\
10^{-18} \\
\mathrm{M}^{3}\end{array}$ & $V p, 10^{-18}, \mathrm{M}^{3}$ & $\begin{array}{c}\text { Квик, } \\
\%\end{array}$ \\
\hline 1 & 0,6 & 40 & 0,01 & 0,15 & 247 & 60 & 0,7 & 393 & $414 \ldots 881$ & - \\
\hline 2 & 1,4 & 40 & 0,015 & 0,25 & 38 & 60 & 0,75 & 9170 & $6940 \ldots 15400$ & 26 \\
\hline 3 & 2,9 & 40 & 0,03 & 0,3 & 20 & 60 & 0,8 & 48750 & $23400 \ldots 53800$ & 83 \\
\hline
\end{tabular}

Об'єм реальної лунки $V p$ буде знаходитися в межах між визначеним об'ємом випаруваного матеріалу та об'ємом розплавленого матеріалу. Експериментально встановлено [1], що за умов, близьких до модельного експерименту, з лунки видаляється від $40 \%$ до $60 \%$ розплавленого і невипаруваного матеріалу.

Визначене за формулою (8) значення середнього об'єму лунки для кожного 3 проаналізованих режимів знаходиться в межах між розрахованими за математичною моделлю об'ємами випаруваного та розплавленого матеріалів. Менше значення середнього об'єму для фінішного режиму, скоріше за все, зумовлено вибором кроку сітки для розрахункової моделі. Подрібнення сітки збільшує точність, але суттєво збільшує час розрахунку. Враховуючи стохастичний характер процесу, точність прогнозування і те, що подібний результат проявився лише в одному, найменш потужному 3 усіх прорахованих режимів, вважатимемо дані, отримані за математичною моделлю, близькими до експериментальних.

\section{Висновки:}

1. У рамках теплової гіпотези шляхом розрахунків за запропонованою математичною моделлю побудовано форми границь фазових переходів, що формуються одиничним розрядом при обробці якісної конструкційної сталі 45 (ГОСТ 1050-88) за використання енер- гетичних параметрів імпульсів, характерних для фінішного, напівчистового та чорнового режимів різання сучасного електроерозійного комплексу AccuteX GE-43SA.

2. Виявлено закономірності зміни енергоефективності процесу руйнування конструкційної сталі 45 (ГОСТ 1050-88) в обраному діапазоні режимів роботи генератора.

3. Порівняння розрахованих об'ємів фазових перетворень матеріалу анода з експериментальними даними підтвердило в цілому задовільну точність прогнозування форми границь фазових переходів.

4. Недоліком використаної математичної моделі є неможливість урахування характеру дії сил, що обумовлюють гідродинаміку поведінки розплавленого металу, його викидання 3 ерозійної лунки та формування облямовуючого валика. Частково цей недолік можливо компенсувати через використання емпіричного коефіцієнта викиду.

5. Отримані результати моделювання та їх аналіз, по суті, відкривають перспективний шлях до мінімізації енергетичних затрат на обробку того чи іншого матеріалу та керування характеристиками оброблених поверхонь як 3 точки зору формування мікрогеометрії, так і глибини зміни структури в зоні термічного впливу. 


\section{Список літератури}

[1] В. І. Осипенко, О. П. Плахотний, та Н. В. Філімонова, Фізика $i$ технологія електроерозійного дротяного вирізання: монографія. Черкас. держ. технол. ун-т. Черкаси: Видавець ФОП Гордієнко Є. І., 2019.

[2] Д. О. Ступак, "Оптимізація процесу енерговиділення в міжелектродному проміжку для умов електроерозійного дротяного різання", автореф. дис. канд. техн. наук: 05.03.07, Нац. техн. ун-т України "Київ. політехн. ін-т", Київ, 2002.

[3] Г. Є. Калейніков, "Електроерозійне дротяне вирізання в середовищі водних розчинів поверхнево-активних речовин", автореф. дис. канд. техн. наук: 05.03.07, Нац. техн. ун-т України "Київ. політехн. ін-т", Київ, 2003.

[4] Б. И. Ставицкий, и Н. Б. Ставицкая, "Исследование форм и размеров эрозионных лунок, образованных на различных материалах искровыми разрядами", Электронная обработка материалов, № 1, с. 913, 1980.

[5] В. І. Осипенко, Д. О. Ступак, та С. В. Поздєєв, "Фізико-технологічні закономірності пробою рідини та балансу енергії одиничного іскрового розряду", Вісник національного технічного університету Украӥни "Київський політехнічний інститут". Машинобудування, c. 273-280, 2009.

[6] В.В.Попович, та В.В.Попович, Технологія конструкційних матеріалів $і$ матеріалознавство: підручник. Львів: Світ, 2006.

[7] А. В. Билан, В. И. Осипенко, Д. О. Ступак, и Я. Д. Король, "Особенности формирования микрогеометрии и физических свойств поверхностных слоев стали при электроэрозионной вырезной обработке и последовательной электроэрозионной и электрохимической обработке проволочным электродом", Уральский научный вестник, № 12 (48), с. 27-34, 2012.

[8] Development of an intelligent process model for EDM. S. N. Joshi \& S. S. Pande, 2009.

[9] J. Marafona, and J. G. Chousal, "A finite element model of EDM based on the Joule effect", Int J. Mach. Tools Manuf., 46 (6), pp. 595-602, 2006.

doi:10.1016/j.ijmachtools.2005.07.017.
[10] S. H. Eo, W. Kurnia, and P. C. Tan, "Critical assessment and numerical comparison of electro-thermal models in EDM", J. Mater. Process Technol., 203, pp. 241-251, 2007. doi:10.1016/j.jmatprotec.2007.10.026.

\section{References}

[1] V. I. Osypenko, O. P. Plakhotnyi, and N. V. Filimonova, Physics and technology of electroerosive wire cutting: a monograph. Cherkasy State Technological University. Cherkasy: Publisher FOP Gordienko E. I., 2019 [in Ukrainian].

[2] D. O. Stupak, "Optimization of the energy release process in the electrode gap for the conditions of electro-erosion wire cutting", M.S. thesis. Dept. Tech. Sciences: 05.03.07, Nat. Tech. University of Ukraine "Kyiv Polytechnic Institute", Kyiv, 2002 [in Ukrainian].

[3] G. E. Kaleynikov, "Electroerosive wire cutting in the environment of aqueous solutions of surfactants", M.S. thesis. Dept. Tech. Sciences: 05.03.07, Nat. Tech. University of Ukraine "Kyiv Polytechnic Institute", Kyiv, 2003 [in Ukrainian].

[4] B. I. Stavitsky, and N. B. Stavitskaya, "The study of the shapes and sizes of erosion holes formed on various materials by spark discharges", Elektronnaya obrabotka materialov, no. 1, pp. 9-13, 1980 [in Russian].

[5] V. I. Osypenko, D. O. Stupak, and S. V. Pozdeev, "Physical and technological regularities of liquid breakdown and energy balance of single spark discharge", Visnyk natsionalnoho tehnichnoho universytetu Ukrayiny "Kyivskyi politehnichnyi instytut". Mashynobuduvannya, pp. 273-280, 2009 [in Ukrainian].

[6] V. V. Popovich, and V. V. Popovich, Technology of structural materials and materials science: a textbook. Lviv: Svit, 2006 [in Ukrainian].

[7] A. V. Bilan, V. I. Osypenko, D. O. Stupak, and Ya. D. Korol, "Features of the formation of microgeometry and physical properties of the surface layers of steel during electrical discharge machining and sequential electrical discharge and electrochemical processing with a wire electrode", Uralskiy nauchniy vestnik, no. 12 (48), pp. 27-34, 2012 [in Russian]. 
[8] Development of an intelligent process model for EDM. S. N. Joshi \& S. S. Pande, 2009.

[9] J. Marafona, and J. G. Chousal, "A finite element model of EDM based on the Joule effect", Int J. Mach Tools Manuf., 46 (6), pp. 595-602, 2006. doi:10.1016/j.ijmachtools.2005.07.017.

[10] S. H. Eo, W. Kurnia, and P. C. Tan, "Critical assessment and numerical comparison of electro-thermal models in EDM", J. Mater Process Technol., 203, pp. 241-251, 2007. doi:10.1016/j.jmatprotec.2007.10.026.

V. I. Osypenko, D.Tech.Sc., professor,

O. V. Timchenko,

A. V. Kondakov

Cherkasy State Technological University, Shevchenko blvd, 460, Cherkasy, 18006, Ukraine

\section{MODELING OF THERMAL PROCESSES OF A SINGLE CRATER FORMATION BY DISCHARGES OF MODERN GENERATORS OF EDM CUTTING MACHINES}

The peculiarities of forming a single crater geometry and heat affected zone depth during wire electrodischarge machining of a high-quality structural steel 45 on machines equipped with modern current generators are considered. With the help of mathematical modeling based on numerical solutions of the axisymmetric quasi-three-phase nonlinear thermal conductivity problem with moving phase boundaries, the curves describing the phase boundaries of the evaporation, material melting and austenitic transformation temperature, depending on energy parameters of the discharge and material thermophysical properties are received. The volumes of the material removed from the crater in the form of steam and liquid are estimated. The data on the energies spent on the phase transformation of the anode material: the melting and evaporation, their share in the total discharge energy applied to the steel anode at different processing modes, as well as the consequences of changing the pulse parameters in each mode are given. It is found that the increase in the pulse duration with increasing the total energy consumed in the electrode gap, leads to the efficiency decrease of overall energy usage for the destruction of the workpiece material. The adequacy of the model is evaluated by comparison with the experimental data, which have been repeatedly confirmed on the equipment of various enterprises. The obtained results open a promising way to minimize energy costs for the processing of materials and control the characteristics of the treated surfaces both in terms of the formation of microgeometry and the depth of structure changes in the heat affected zone. This, in its turn, will allow to expand the limits of the erosion technology application by increasing economic benefits from the use of the described method. In addition, the above-mentioned creates preconditions for new effective designs of technological modes of subsequent electrochemical dimensional machining with a fixed wire electrode, since the depth of the heat affected zone is an important factor in determining the allowance which needs to be removed in electrochemical surface modification.

Keywords: electro-discharge machining, impulse energy, heat-affected zone.

Стаття надійшла 30.08.2019

Прийнято 14.09.2019 